\title{
The Ottawa Field-Naturalists' Club Awards for 2013, presented April 2014
}

\author{
Eleanor Zurbrigg, Irwin Brodo, Julia Cipriani, Christine Hanrahan, and Ann MacKenzie
}

On April $26^{\text {th }}, 2014$ members and friends of the Ottawa Field-Naturalists' Club gathered for the Club's Awards Night at St. Basil's Church in Ottawa to celebrate the presentation of awards for achievements in the previous year. Awards are given to members or non-members who have distinguished themselves by accomplishments in the field of natural history and

\section{Member of the Year: Mark Brenchley}

The OFNC's Member of the Year award recognizes the member judged to have contributed the most to the Club in the previous year.

We are recognizing Mark Brenchley for his positive, creative and enthusiastic commitment. Mark Brenchley joined the OFNC in 2012 upon his return to Ottawa. In late 2012 and throughout 2013 he jumped in to support the Education and Publicity Committee. His energy, skills and ideas were pivotal to the completion of several projects designed to enhance the profile of the Club.

When Ontario Nature invited naturalist clubs to sponsor a youth to attend the Ontario Nature Youth Summit last year, the request landed in the hands of the Education and Publicity Committee. Mark stepped up to design an application process to select a candidate to represent the Club. He communicated with school boards, scouting groups and the members of the Club to generate interest in the opportunity. Three applications came back to him. Mark, Suzanne Deschênes and Lynn Ovenden interviewed the candidates and selected Sarah Wray, a grade 10 student at Nepean High School. After the Summit, Mark invited Sarah to describe her experience at a monthly meeting in the Fall and asked her to write a report which was published in the 2014 Winter issue of Trail and Landscape.

Had Mark not taken the Ontario Nature initiative, the club would have missed an opportunity to support the Summit and Sarah. Thanks to his initiative, there is a framework in place to support the Club's future participation.

Over the year, Mark worked on a series of promotional items and signs, all bearing the OFNC's owl logo, the club name and often the website on a forest conservation or by extraordinary activity within the Club. Three awards were presented for 2013, recognizing achievement in enhancing the profile of the Club, long time service as editor for one of the Club's publications, and success in raising awareness of environmental stewardship and respect for nature in the primary school program. green background. He made an $8^{\prime}$ long banner that tops our tent and display table at public events. When Education and Publicity wanted to offer hand lenses on a club lanyard at the monthly meeting sales table, Mark created the logo file and placed the order with the lanyard imprinting company. Then he coordinated the logo design and purchase of the lens wipe pouches which clip onto a lanyard or binocular strap. He led the design of a promotional bookmark which includes photos and the Club website.

The OFNC Council realized a few years ago that the sign at the entrance to Fletcher Wildlife Garden is a highly visible spot, a great place to increase public awareness of OFNC. Although there has been a sign on Prince of Wales Drive to direct people to the Garden, there was nothing to indicate the OFNC's involvement with the Garden. Since Mark is in the sign business, he was asked what could be done. As a result he designed and installed a dark green aluminum panel with the OFNC owl and our website atop the existing Fletcher sign clearly identifying the Fletcher Wildlife Garden with the OFNC, all at minimal cost to the Club.

Through these products Mark has developed several graphic files with the OFNC's logo and wordmark. He continues to work at "branding" the OFNC with the goal to create a recognizable visual identity for all Clubrelated materials, promotional items and signage.

Mark is a cheerful, engaging salesman behind the display table at most monthly meetings and at some of OFNC's public events. It is for his many contributions to promoting the Club in 2013 that we want to recognize Mark as Member of the Year.

(Written by Julia Cipriani based on information
and feedback from Lynn Ovenden)

\section{George McGee Service Award: Karen McLachlan Hamilton}

The OFNC George McGee Service Award is given in recognition of a member who has contributed significantly to the smooth running of the Club over several years.

This year, the award goes to Karen McLachlan Hamilton, long-serving editor of Trail \& Landscape.
All club members are familiar with our quarterly publication, more commonly known as $T \& L$, in which news of the club, regional biological and conservation reports and articles by members, lists of upcoming events, poems, photos and much else is published. Every three months, this lively and informative publication arrives 
in our mailboxes, to be enjoyed and savoured. I would guess, however, that many of us give little thought to the work and effort that ensures $T \& L$ lands in our laps four times a year!

From its inception in 1967, when it was produced five times a year, to today's much more substantial quarterly, Trail \& Landscape has had only 6 editors, as each tends to stay for a long time. Karen McLachlan Hamilton has served in that capacity since 2001 and has overseen the production of more issues (52 to the end of 2013) than anyone since founding editor Anne Hanes (65 issues).

Karen is responsible for seeking articles, editing them for technical accuracy and presentation, providing feedback and suggestions to authors, and making sure the publication is ready for the printer. In this, she is helped by an associate editor, a production coordinator and a mailing team. But the ultimate responsibility for ensuring the quality and production standards of $T \& L$ (presentation and timing etc.), is Karen's. No sooner has she put one issue "to bed", than she is working on the next, for there is little downtime in this business. It is astonishing that Karen, with a full-time job, is able to maintain this hectic schedule with professionalism and grace. While an honorarium goes along with the position of Editor, it does not begin to compensate for the actual work and time that goes into this process. And besides, Karen has always refused to accept the stipend. It is indeed, a labour of love.

Karen not only edits $T \& L$, she also writes many articles for it, such as the annual summary of the OFNC's Soiree and Awards Ceremony. She has also written numerous book reviews for $T \& L$, which are characterized by a forthright discussion of the books in question, incisive comments on content, and descriptive information on the books themselves. Karen is also a long-serving member of the OFNC Board of Directors and the club's Publications Committee.

For all these reasons, we believe that Karen is very well deserving of this award to recognize her long service on behalf of the OFNC.

(Written by Christine Hanrahan)

\section{Mary Stuart Education Award: Angelika Skevington}

The Mary Stuart Education Award is given in recognition of outstanding achievements in the field of natural history education in the Ottawa Region.

Angela Skevington is the recipient of this award for 2013. Angela is a primary school teacher who is passionate about natural history education. For over 15 years she has taught a variety of grades in different schools, sharing her dedication to good environmental stewardship and her knowledge and wonder of nature with her students every day, every year. Currently Angela teaches a combined Grade 4/5 class at Huntley Centennial Public School in the village of Carp near Ottawa.

Wherever she works, Angela has championed such environmental programs as EarthCare Canada and more recently Ontario EcoSchools. Last year her school was recognized with a silver level EcoSchool certification. This achievement required years of diligent effort on Angela's part to engage students and the school community in activities across the 6 areas of environmental practice rated by the EcoSchool Program, including waste minimization and energy conservation. Each school year, she instigates a student-led club (previously called an EarthCare Club, currently dubbed The Dragonflies) that undertakes environmental projects, such as a periodic audit of their school's energy and waste practices. If the audit indicates that there is a problem, such as improper waste disposal, then The Dragonflies club delivers classroom presentations to fellow students demonstrating the proper practice, such as how to separate garbage for recycling. The students in The Dragonflies club also put on plays at school as- semblies to demonstrate proper energy and waste practices. Last year, Angela piloted "litterless lunches" with her class. The Dragonflies promoted the idea and this year the whole school is litter-free at lunch. There are many more examples. Through this hands-on practice, students learn how to be active environmental stewards.

For the past 3 years, Angela has participated in Ottawa's Clean up the Capital Day. She enlisted classes that were interested in being involved, applied through the City of Ottawa to get materials (bags, gloves) and then they cleaned up the school grounds.

On Earth Day, Angela has conducted student plays at the school assemblies featuring pollution, anti-littering, proper recycling. She also encourages the students to create and perform skits, songs and presentations. She does this every year to promote celebration of the natural environment and good environmental stewardship.

Field trips and nature appreciation are important parts of Angela's teaching. Habitat is part of the Grade 4 curriculum. She has successfully applied through Ducks Unlimited Canada's Project Webfoot for funding for field trips to a local wetland (such as the Bill Mason Outdoor Education Centre). They have also had field trips to the Bonnechere Caves.

In addition to all of this, Angela leads informal lunchtime field trips for interested students to a nearby natural area, to learn about and develop an appreciation for nature. One day they may focus on birds, the next day on insects, and the third on plants. She applied for and received funding to organize a field trip for The Dragonflies club for a day to learn about bird banding at Innis Point Bird Observatory. The children were excit- 
ed to each hold a chickadee or nuthatch. On breaks they played nature games in the field, and went on a nature hike.

Angela teams up with her husband Jeff Skevington to help him lead "kid friendly" field trips for The Ottawa Field-Naturalists' Club as well as for other nature clubs in the Ottawa Valley. Angela assisted Jeff and colleagues in hosting a well-attended Bug Day held at the Fletcher Wildlife Garden last year.

Angela's efforts are recognized and appreciated, as evidenced by fellow teacher Donna Christie who said:
"I feel honoured to work with Angela and know that she has made a positive impact on her students and our school .... She is a scientifically-oriented, dedicated, hard-working educator."

The OFNC is delighted to present the Mary Stuart Education Award for 2013 to Angela in recognition of her success in raising awareness of environmental stewardship and respect for nature at her school and more broadly.

(Prepared by Eleanor Zurbrigg with input from Donna Christie) 